SYSTEMATIC REVIEW

\title{
Using the CDC's Worksite Health ScoreCard as a Framework to Examine Worksite Health Promotion and Physical Activity
}

\author{
Leah K. Gutermuth, MPH, CHES ${ }^{1}$; Erin R. Hager, $\mathrm{PhD}^{1}$; Keshia Pollack Porter, PhD, MPH ${ }^{2}$
}

Accessible Version: www.cdc.gov/pcd/issues/2018/17_0463.htm

Suggested citation for this article: Gutermuth LK, Hager ER, Pollack Porter K. Using the CDC's Worksite Health ScoreCard as a Framework to Examine Worksite Health Promotion and Physical Activity. Prev Chronic Dis 2018;15:170463. DOI: https://doi.org/ 10.5888/pcd15.170463.

\section{PEER REVIEWED}

\section{Abstract}

\section{Introduction}

Worksite health promotion programs are emerging as an effective approach for addressing the adult obesity epidemic and improving the overall health of employees.

\section{Methods}

We conducted a scoping review to identify articles that described a physical activity component (eg, promoted increased physical or reduced sitting time) of a worksite health promotion intervention. Our search specified full-length articles published in English from January 2000 through July 2015. We used the Centers for Disease Control and Prevention's Worksite Health ScoreCard, a validated tool, as a framework to summarize information on organizational supports strategies (18 questions) and physical activity strategies (9 questions) implemented by worksite health promotion programs. We also determined whether or not the included studies reported significant $(P<.05)$ improvements in physical activity.

\section{Results}

We identified 18 worksite health promotion programs; 11 produced significant improvements in physical activity. Incentives, health risk assessments, health promotion committees, leadership support, marketing, and subsidies or discounts for use of exercise facilities were the most effective organizational supports strategies cited, and physical activity seminars, classes, and workshops were the most effective physical activity strategies cited.

\section{Conclusion}

The use of the Health ScoreCard allowed for a practical interpretation of our findings, which can inform next steps for the field. Future research should explore the relationships between components of worksite health promotion programs and their outcomes to further develop best practices that can improve worker health and promote physical activity.

\section{Introduction}

Worksite health promotion programs are an effective approach for improving the overall health of working adults in the United States (1). Nearly $38 \%$ of American adults are obese (2). Because the average employee spends 7.6 hours per day at work (3), the workplace is an important place in which to influence the behavioral and environmental determinants of obesity (4). Worksite health promotion programs that focus on improving nutrition, physical activity, or both have produced reductions in weight and body mass index (5). Worksite health promotion programs may be a powerful, cost-effective strategy to prevent obesity and promote health among US adults (6-10).

The Centers for Disease Control and Prevention's (CDC's) Worksite Health ScoreCard (HSC) is a tool for employers to assess the implementation of evidence-based worksite health promotion interventions (11). The HSC consists of 16 components that each include a list of evidence-based strategies. It has been used by state health departments, worksites, and their partners as a tool to expand implementation of evidence-based worksite practices, assist with creating sustainable programs, assess implementation, evaluate environmental changes, and track program components (12). 
This review had 2 primary objectives: 1) to use the HSC as an evidence-based framework to examine physical activity strategies of worksite health promotion programs, and 2) to compare the frequency of using selected worksite health promotion strategies (included in the HSC) among programs that reported improving physical activity among employees.

\section{Methods}

We conducted a scoping review in August through October 2015. A scoping review is a synthesis of the literature, typically conducted as a preliminary investigation to identify the range and nature of existing research (13). Scoping reviews provide insight into gaps in research (13). Our review aimed to identify articles that described a physical activity component (eg, promoted increased physical or reduced sitting time) of a worksite health promotion intervention and to determine which strategies were most effective.

We identified articles by using the OneSearch engine (www.hshsl.umaryland.edu). This search engine provides an access point to 60 databases; a single search on OneSearch can identify articles from various search engines. We used the following keywords to find peer-reviewed articles that were published from January 2000 through July 2015: "worksite health promotion" or "employee health" and "physical activity." To further identify potential articles, we added the search terms "organizational support" or "policy." We reviewed titles and abstracts for studies that focused on improving physical activity behaviors. To supplement the search, we examined reference lists from relevant articles. The article selection was driven by a logical approach that partly reflected our own opinion and expertise in the field of worksite health promotion. We did not limit the search to specific study designs, outcomes, or worksite characteristics (eg, sex or age of participants; size, setting, number of employees; location of worksite).

\section{Study selection}

After an initial search, we reviewed titles and abstracts to determine articles that met inclusion criteria. The following inclusion criteria were used: the intervention took place in a workplace, the program included components that involved physical activity, and the study was published in English. We excluded any articles that did not provide enough details about the program components to analyze by using the HSC. Only full-length articles were considered. After an initial screening of the articles, we selected 18 for review; they were published from 2002 to 2015. Because we did not limit the types of studies designs that were included for this review, we did not systematically evaluate the quality of the evidence.

\section{Data extraction}

The HSC covers 16 topics (eg, tobacco control, nutrition, stress management, physical activity, organizational supports). We focused on the topics of physical activity and organizational supports (Table 1). These were selected because physical activity has stronger benefits for disease prevention, weight control, mental health, stress management, and productivity compared with other topics of the HSC $(14,15)$, and because a perception of organizational commitment is associated with physical activity outcomes (16-18). CDC defines each topic with a set of questions, or strategies (18 for organization supports and 9 for physical activity). We selected these strategies because worksite physical activity that incorporates environmental support, coaching, and a combination of physical activity components has potentially positive effects on employee weight outcomes (19-22).

The HSC assigns point values of 1,2 , or $3(1=$ good, $2=$ better, and $3=$ best) to indicate the level of effect each strategy has on the associated health topic or outcome and the strength of evidence for this effect (eg, brochures $=1$ point, lifestyle counseling $=3$ points). Among the 18 organizational supports strategies included in the HSC, 5 are categorized as good, 11 as better, and 2 as best. Among the 9 physical activity strategies, one is categorized as good, one as better, and 7 as best.

The lead author (L.K.P.) searched for strategies listed in the HSC and extracted information on these strategies from the articles. The lead author then sent a random sample of articles for abstraction to the 2 coauthors. This process revealed consistency in abstraction and validated the abstraction conducted by the lead author. We assessed 25 of the 27 HSC organizational supports and physical activity strategies. We chose not to extract information on 2 HSC strategies described by the following questions: "During the past 12 months, did your worksite "have an annual budget or receive dedicated funding for health promotion programs?" (better) and "provide free or subsidized self-management programs for physical activity?" (best). We did not extract this information because all the included studies had a physical activity program (a criterion for inclusion) and all had some type of funding, which meant that these measures would not vary. We included the strategy described by the question "During the past 12 months, did your worksite conduct ongoing evaluations of health promotion programming that use multiple data sources?," but all studies confirmed multiple data sources.

We reviewed and assessed articles by using the HSC as a framework for evaluating the relevant organizational supports and physical activity strategies of each program. The lead author (L.K.P.)

\footnotetext{
The opinions expressed by authors contributing to this journal do not necessarily reflect the opinions of the U.S. Department of Health and Human Services, the Public Health Service, the Centers for Disease Control and Prevention, or the authors' affiliated institutions.
} 
used the HSC strategies as a checklist for each article. After creating the side-by-side comparison of HSC strategies by study, we then determined whether the studies reported significant $(P<.05)$ improvements in physical activity.

\section{Results}

Eighteen articles were identified, and all included an intervention; however, the study designs varied. Ten studies used randomization (23-32), including wait-list control groups $(24,25,31)$, random allocation (23,27-30,32), and a crossover design (26). Among the 8 remaining studies, 5 used a single-group pre-post design (33-37), 1 employed a non-randomized controlled trial (38), 1 used a non-randomized interrupted-time-series approach (39), and 1 used a quasi-experimental design (40). Five of the studies were pilot studies $(26,34,36,37,40)$, and 4 were feasibility studies $(24,29,32,35)$ (Table 2).

Studies targeted a diverse group of worksites, including deskbased $(24,26,34,37-39)$, manufacturing $(25,27,29,31,36)$, and health care worksites $(23,33,40)$. Two studies conducted programs in multiple settings (eg, a university and a bus company) $(30,35), 1$ study evaluated a public school setting (28), and 1 study evaluated a university setting (32).

Sample sizes varied, both in number of worksites and number of employees enrolled or evaluated. Twelve studies assessed a single worksite $(23,26,27,29,31-34,36-39)$, and 6 studies tested their worksite health promotion program in multiple worksites $(24,25,28,30,35,40)$. Most studies enrolled or evaluated fewer than 100 participants, with 5 evaluating 50 or fewer participants (26,37-40) and 5 evaluating 51 to 100 participants $(24,29,32,34,35)$. Three studies included 101 to 249 participants $(23,27,31)$. Larger studies included those enrolling 250 to 749 participants $(25,36)$ and more than $750(28,30,33)$. Multiple countries were represented in the included studies. Only 7 of 18 studies were conducted in the United States $(23,25,27,28,37,39,40)$.

\section{Intervention component: organizational supports}

Best. Five studies mentioned tailoring program and education materials to the target population. Three studies conducted employee health risk assessments (HRAs) $(25,33,36)$.

Better. All studies positively answered the organizational supports question, "During the past 12 months, did your worksite conduct ongoing evaluations of health promotion programming that use multiple data sources?" Nine studies provided incentives for participating in the intervention study $(23,25,26,31,33-35,37,40)$, and
1 study provided incentives for participating in the wellness program as a whole (39). Eight studies reported involvement and support from management $(26,30,33,34,36-39)$. Seven studies used natural helpers or peer champions as advocates of the program $(25,28,30,33,35,37,40)$.

Five studies used competitions to support employees in making behavior changes $(28,30,33,35,40)$. Flexible work schedule policies were found in 5 studies $(29,33,36,39,40)$. Four studies $(24,28,33,38)$ mentioned a designated health promotion coordinator, but only 1 indicated that the health promotion responsibilities were part of their paid employment and job responsibilities (33), 1 was a designated liaison between the research team and employees (38), 1 was named team leader of the health and well-being group (24), and 1 indicated that a stipend was provided (28). Three studies mentioned a health promotion committee $(34,38,39)$. One study discussed annual health promotion organizational objectives (33). One study mentioned engaging in other health initiatives in the community (33).

Good. Program promotion and marketing efforts were found in 9 studies $(23,26,27,30,32-34,37,40)$. Flyers and newsletters were used in 5 studies $(23,26,27,32,40), 2$ studies used branded programs and logos $(30,33)$, and 1 study offered a program kick-off party (37). Finally, only 1 study mentioned including family members in the worksite health promotion program (23), 1 study mentioned using role modeling to promote behavior change (30), 1 study conducted an employee needs assessment for planning health promotion activities (33), and 1 study included employee health in business objectives/organizational mission statement (37).

\section{Intervention component: physical activity}

Best. Nine studies used physical activity programs (other than the use of an exercise facility) $(24,25,28,32,33,35-37,40)$. Among these studies, 6 provided on-site exercise classes $(28,33,35-37,40), 5$ used walking groups $(24,25,28,32,35), 2$ used structured physical activity breaks $(37,40)$, and 2 used stretching classes $(25,36)$. Five studies provided other environmental supports for physical activity $(24,28,32,33,40)$. Four studies provided maps of walking routes $(24,28,32,33), 1$ provided locker rooms (28), and 1 provided video games and DVDs on-site to promote physical activity onsite when the interventionist was not there (40). Four studies provided on-site exercise facilities $(28,33,35,40)$. Two studies subsidized or discounted gym memberships $(26,33)$. One study indicated promoting the use of stairs (33).

Five studies included fitness assessments with follow-up counseling $(23,29,34,38,40)$. Four studies used pedometers $(23,29,34,40)$, and 2 studies used accelerometers (26,38). Follow-up counseling

The opinions expressed by authors contributing to this journal do not necessarily reflect the opinions of the U.S. Department of Health and Human Services, the Public Health Service, the Centers for Disease Control and Prevention, or the authors' affiliated institutions. 
included dietitians and medical professionals (23), occupational health nurses (34), nursing assistants (40), masters-level health coaches (38), and personalized weekly emails about step counts and health information (29).

Better. Nine studies incorporated educational classes or seminars addressing physical activity $(23,25,27,31,33,34,36,38,40)$. Among these, 1 study provided an educational class summarizing the health consequences of excessive sitting (38). Eight studies conducted face-to-face sessions $(23,25,31,33,34,36,38,40)$, and 1 study provided online video classes (27).

Good. Eleven studies provided employees with information on the benefits of physical activity $(23,25,27-31,33-36)$, and 1 study provided information about the benefits of sitting less (38). One study indicated that physical activity resources were provided but did not specify what types of resources were provided (39).

\section{Effect of worksite health promotion program on physical activity and alignment with HSC}

Table 3 shows the frequency of HSC strategies (organizational supports and physical activity) among the studies included in this review, including a comparison of HSC strategies did and did not result in significant $(P<.05)$ improvements in physical activity. All studies targeted physical activity; 15 studies also measured physical activity behavior. Studies that did not measure physical activity behavior measured readiness to change physical activity (36), physical activity quality of life (31), and implementation of physical environment and policy intervention strategies (eg, implementation of a walking group) (28).

Eleven studies showed significant improvements $(23,25-27,32-36,38,39)$. Examples of physical activity improvements include the following: general increased physical activity $(27,32,33)$, decreased sitting time $(26,38,39)$, increased steps $(23,34)$, increased standing time $(26,38)$, stretching/flexibility (25), days of physical activity (35), minutes of physical activity (27), active travel (33), increased activity at work (33), and increased readiness to change (36).

Organizational supports. The most common HSC organizational supports strategies that produced significant physical activity improvements were leadership support, incentives, and marketing. Among the 8 studies demonstrating leadership support, 6 produced improvements in physical activity or sitting behaviors $(26,33,34,36,38,39)$. Among the 8 studies that indicated using promotion and marketing, 5 produced significant physical activity improvements $(23,26,27,32,33)$. Among the 10 studies that used or combined incentives with other strategies, 7 produced significant results $(23,25,26,33-35,39)$.
In a comparison of the organizational supports HSC strategies that resulted in physical activity improvements and those that did not result in improvements, 5 strategies that resulted in improvements emerged: leadership support, incentives, employee HRAs, active health promotion committees, and marketing (Table 3). All 3 studies that had an active health promotion committee $(34,38,39)$ and that conducted employee HRAs had significant improvements $(25,33,36)$.

Physical activity. Of the 11 studies with significant physical activity improvements, the 4 most common physical activity HSC strategies were 1) providing information on the benefits of physical activity; 2) providing physical activity classes, seminars, or workshops; 3 ) providing organized physical activity programs; and 4) providing or subsidizing fitness assessments, follow-up counseling, and physical activity recommendations. Seven of 11 studies that provided information on the benefits of physical activity had significant improvements $(23,25,27,29,34-36)$. However, 4 of the 7 studies that did not produce significant improvements also included information on physical activity benefits $(29-31,40)$.

Among the 9 studies that provided physical activity seminars, workshops or classes, 7 had significant improvements $(23,25,27,33,34,36,38)$. Among the 9 studies that provided organized individual or group physical activity programs, 5 had significant improvements $(25,32,33,35,36)$. However, 4 of the 7 studies that did not produce significant improvements also provided organized programs to employees $(24,28,37,40)$.

In a comparison of the physical activity HSC strategies that resulted in physical activity improvements and those that did not result in improvements, 2 components that resulted in significant improvements emerged: subsidizing or discounting the cost of exercise facilities and providing physical activity seminars, classes, and workshops (Table 3).

\section{Discussion}

The worksite provides an important setting for addressing the adult obesity epidemic and improving the health of the working population by targeting physical activity. Research consistently demonstrates a relationship between worksite health promotion programs and improvements in health behaviors of employees. This scoping review highlights evidence-based worksite health promotion strategies promoted through the CDC's HSC. The HSC organizational supports strategies of leadership support (better), incentives (better), employee HRAs (best), and active health promotion committees (better) and the physical activity strategies of subsidizing or discounting the cost of exercise facilities (best) and providing physical activity seminars, classes, and workshops (better) showed the greatest impact on physical activity improvement.

\footnotetext{
The opinions expressed by authors contributing to this journal do not necessarily reflect the opinions of the U.S. Department of Health and Human Services, the Public Health Service, the Centers for Disease Control and Prevention, or the authors' affiliated institutions.
} 
Each of these findings can be used to guide recommendations for future worksite health promotion research and practice. All notable strategies were categorized, by using a point system, as either better or best, reinforcing the importance of these components. Using the HSC to synthesize these findings also demonstrates the need to promote the use of a framework for worksite health promotion planning and evaluation.

Although improvements were found among programs using leadership support, less than half of the studies used leadership support, and even fewer studies implemented policies, such as flexible scheduling or paid breaks, that support the worksite health promotion program in encouraging employees to engage in physical activity. Leadership support increases worksite health promotion participation, reduces job stress, and improves health behavior (41-44). These studies demonstrate areas of focus for future worksite health promotion programs. Leadership support and other key HSC organizational supports strategies should be further explored and assessed, including the strategies that did not have a significant effect on physical activity, such as using competitions, having a paid health promotion coordinator, having champions advocate for the program, using role modeling and success stories in marketing, and including health in business objectives, to further understand the importance of creating a supportive worksite health promotion environment for employees.

Similarly, although the use of health champions was common in our studies, the lack of physical activity improvement raises questions about the definition of a health champion, the types of incentives health champions are offered, and the relationship between health champions and coworkers. Previous studies found that some of the best strategies for improving employee health include using leaders as mentors and champions of workplace values (45), creating a corporate culture that acknowledges the importance of employee health and offering participation-friendly corporate policies and physical environments (46). Future worksite health promotion research should explore the effectiveness of organizational supports strategies and their effect on both healthrelated outcomes and job satisfaction outcomes.

We observed a trend among interventions demonstrating improvements in physical activity behaviors and the use of activity trackers. Although the use of activity trackers is not included in the HSC, 9 of the 11 studies that showed improvements in physical activity behaviors or activity at work used pedometers $(23,24,29,32-35)$ or accelerometers $(26,38)$. Therefore, the inclusion of a pedometer or other activity tracker, other than or in addition to self-report, could be a key contributing factor to motivating participants to increase their activity levels. The addition of an activity tracker strategy to the HSC could be considered.
Finally, the role of organizational supports may strongly influence program effectiveness through incentives, HRAs, leadership support, health promotion committees, and marketing. Previous studies identified the positive impact of organizational supports on employee well-being and work engagement $(47,48)$. We also found that organizational supports strategies had an impact on physical activity. A greater number of organizational supports strategies (n $=3)$ than physical activity strategies $(n=2)$ produced significant physical activity improvements. This finding reinforces the importance of creating a supportive workplace environment and culture when targeting physical activity behaviors. Future physical activity worksite health promotion programs should promote and evaluate organizational supports strategies in addition to physical activity outcomes.

Studies that incorporate needs assessments to gauge employee preferences for health topics, program components, and availability are lacking. A mismatch between employee interests, schedules, and availability and the worksite health promotion program may limit program participation (49). Although many programs provided a rationale for the health topic of interest, only 1 study directly collected feedback on employee preferences before launching the program. Asking employees about their preferences could provide critical insight into motivating employees to participate, resulting in a more effective program.

Lack of time is a consistent barrier to making health behavior changes among working adults (50). Providing programs at the worksite provides a realistic strategy for overcoming this barrier while also reaching overweight or obese working adults. The interventions assessed in this study demonstrate the potential effectiveness of worksite health promotion programs in helping adults improve physical activity behaviors, which can result in improvements in body mass index and other health-related outcomes, such as blood pressure and cholesterol levels. The workplace can also promote sustainability of behavior changes because working adults spend consistent, substantial amounts of time there.

One potential limitation of this review is the methodology of the literature search, which may have excluded some studies in the initial screening. Publication bias might also have been a limitation, given that all studies included in the review reported positive program outcomes. Additionally, the methods outlined by the authors in their articles were used to complete portions of the HSC. If intervention methods were not fully described in an article, then they would not have been reported in our review.

Studies included in our review had some methodological limitations, which may have affected some of our conclusions. For example, some studies lacked randomization and use of a control group, which may have limited their internal validity. Many stud-

The opinions expressed by authors contributing to this journal do not necessarily reflect the opinions of the U.S. Department of Health and Human Services, the Public Health Service, the Centers for Disease Control and Prevention, or the authors' affiliated institutions. 
ies enrolled fewer than 100 participants, which likely limited the generalizability to larger worksites. Selection bias may have also been present since employees who are motivated and healthy may be more likely to participate in worksite health promotion program than employees who are less motivated and less healthy. The length of worksite health promotion programs and follow-up period also varied; some programs may not have been in operation long enough to realize program effects.

Despite these limitations, our review used a novel approach to identify key strategies implemented by effective worksite health promotion programs. Organizational-level policies such as incentives, HRAs, health promotion committees, and demonstrations of leadership support may be more likely than other policies to improve employee physical activity and, potentially, productivity. The inclusion of the HSC provided insight into program components that affect physical activity behaviors. Our results could be used to inform workplace wellness committees and decision makers in occupational settings about policies and organizational supports that facilitate healthy behavior changes, especially for physical activity. Future research should focus on using the HSC framework to assess worksite health promotion programs and finding effective strategies for motivating workers to stay engaged in worksite health promotion programs.

\section{Acknowledgments}

This work was supported by the Physical Activity Policy Research Network Plus (PAPRN+), a product of a Prevention Research Center, through a cooperative agreement (U48DP005045) from CDC. The conclusions, findings, and opinions expressed by the authors do not necessarily reflect the official position of CDC or the authors' affiliated institutions. All authors declare no conflicts of interest. Copyrighted materials, surveys, instruments, and tools were not used.

\section{Author Information}

Corresponding Author: Leah K. Gutermuth, MPH, CHES, Department of Pediatrics, Growth and Nutrition Division, University of Maryland School of Medicine, 737 W. Lombard St, 163, Baltimore, MD 21201. Telephone: 443-564-1917. Email: Lperrotta92@umaryland.edu.

Author Affiliations: ${ }^{1}$ Department of Pediatrics, Growth and Nutrition Division, University of Maryland School of Medicine, Baltimore, Maryland. ${ }^{2}$ Department of Health Policy and Management, Johns Hopkins Bloomberg School of Public Health, Baltimore, Maryland.

\section{References}

1. TransAmerica Center for Health Studies. From evidence to practice: workplace wellness that works. 2015. https:// www.transamericacenterforhealthstudies.org/docs/defaultsource/wellness-page/from-evidence-to-practice---workplacewellness-that-works.pdf?sfvrsn=2. Accessed April 16, 2018.

2. Flegal KM, Kruszon-Moran D, Carroll MD, Fryar CD, Ogden CL. Trends in obesity among adults in the United States, 2005 to 2014. JAMA 2016;315(21):2284-91.

3. US Department of Labor, Bureau of Labor Statistics. American time use survey: 2015 results [press release]. US Department of Labor. Friday, June 24, 2016. https://www.bls.gov/ news.release/archives/atus_06242016.pdf. Accessed April 16, 2018.

4. Park S, Pan L, Lankford T. Relationship between employment characteristics and obesity among employed U.S. adults. Am J Health Promot 2014;28(6):389-96.

5. Anderson LM, Quinn TA, Glanz K, Ramirez G, Kahwati LC, Johnson DB, et al. The effectiveness of worksite nutrition and physical activity interventions for controlling employee overweight and obesity: a systematic review. Am J Prev Med 2009;37(4):340-57.

6. Fernandez ID, Chin NP, Devine CM, Dozier AM, Martina CA, McIntosh S, et al. Images of a healthy worksite: a grouprandomized trial for worksite weight gain prevention with employee participation in intervention design. Am J Public Health 2015;105(10):2167-74.

7. Mache S, Jensen S, Jahn R, Steudtner M, Ochsmann E, Preuß G. Worksite health program promoting changes in eating behavior and health attitudes. Health Promot Pract 2015; 16(6):826-36.

8. Baker KM, Goetzel RZ, Pei X, Weiss AJ, Bowen J, Tabrizi MJ, et al. Using a return-on-investment estimation model to evaluate outcomes from an obesity management worksite health promotion program. J Occup Environ Med 2008; 50(9):981-90.

9. Davis J, Clark B, Lewis G, Duncan I. The impact of a worksite weight management program on obesity: a retrospective analysis. Popul Health Manag 2014;17(5):265-71.

10. Salinardi TC, Batra P, Roberts SB, Urban LE, Robinson LM, Pittas AG, et al. Abstract 13112: A lifestyle intervention reduces body weight and improves cardiometabolic risk factors in worksites. Circulation 2012;126(21,Supplement):A13112.

\footnotetext{
The opinions expressed by authors contributing to this journal do not necessarily reflect the opinions of the U.S. Department of Health and Human Services, the Public Health Service, the Centers for Disease Control and Prevention, or the authors' affiliated institutions.
} 
11. Centers for Disease Control and Prevention. The CDC Worksite Health ScoreCard: an assessment tool for employers to prevent heart disease, stroke, \& related health conditions. 2014. http://www.cdc.gov/dhdsp/pubs/docs/hsc_manual.pdf. Accessed March 13, 2018.

12. Meador A, Lang JE, Davis WD, Jones-Jack NH, Mukhtar Q, $\mathrm{Lu} \mathrm{H}$, et al. Comparing 2 national organization-level workplace health promotion and improvement tools, 2013-2015. Prev Chronic Dis 2016;13:E136.

13. Rumrill PD, Fitzgerald SM, Merchant WR. Using scoping literature reviews as a means of understanding and interpreting existing literature. Work 2010;35(3):399-404.

14. US Department of Health and Human Services. President's Council on Sports, Fitness \& Nutrition. Importance of physical activity. 2017. https://www.hhs.gov/fitness/be-active/ importance-of-physical-activity/index.html. Accessed December 11, 2017.

15. Centers for Disease Control and Prevention. Workplace health promotion. https://wwwcdcgov/workplacehealthpromotion/ indexhtml. Updated May 17, 2017. Accessed December 11, 2017.

16. Lemon SC, Zapka J, Li W, Estabrook B, Magner R, Rosal MC. Perceptions of worksite support and employee obesity, activity, and diet. Am J Health Behav 2009;33(3):299-308.

17. Pronk NP, Kottke TE. Physical activity promotion as a strategic corporate priority to improve worker health and business performance. Prev Med 2009;49(4):316-21.

18. Tabak RG, Hipp JA, Marx CM, Brownson RC. Workplace social and organizational environments and healthy-weight behaviors. PLoS One 2015;10(4):e0125424.

19. To QG, Chen TTL, Magnussen CG, To KG. Workplace physical activity interventions: a systematic review. Am J Health Promot 2013;27(6):e113-23.

20. Ausburn TF, LaCoursiere S, Crouter SE, McKay T. Review of worksite weight management programs. Workplace Health Saf 2014;62(3):122-6, quiz 127.

21. Tucker S, Farrington M, Lanningham-Foster LM, Clark MK, Dawson C, Quinn GJ, et al. Worksite physical activity intervention for ambulatory clinic nursing staff. Workplace Health Saf 2016;64(7):313-25.

22. Kahn-Marshall JL, Gallant MP. Making healthy behaviors the easy choice for employees: a review of the literature on environmental and policy changes in worksite health promotion. Health Educ Behav 2012;39(6):752-76.

23. Aldana SG, Greenlaw RL, Diehl HA, Salberg A, Merrill RM, Ohmine $\mathrm{S}$. The effects of a worksite chronic disease prevention program. J Occup Environ Med 2005;47(6):558-64.
24. Brown DK, Barton JL, Pretty J, Gladwell VF. Walks4Work: assessing the role of the natural environment in a workplace physical activity intervention. Scand J Work Environ Health 2014;40(4):390-9.

25. Campbell MK, Tessaro I, DeVellis B, Benedict S, Kelsey K, Belton L, et al. Effects of a tailored health promotion program for female blue-collar workers: health works for women. Prev Med 2002;34(3):313-23.

26. Chau JY, Daley M, Dunn S, Srinivasan A, Do A, Bauman AE, et al. The effectiveness of sit-stand workstations for changing office workers' sitting time: results from the Stand@Work randomized controlled trial pilot. Int $\mathbf{J}$ Behav Nutr Phys Act 2014;11(1):127.

27. Irvine AB, Philips L, Seeley J, Wyant S, Duncan S, Moore RW. Get moving: a web site that increases physical activity of sedentary employees. Am J Health Promot 2011; 25(3):199-206.

28. Lemon SC, Wang ML, Wedick NM, Estabrook B, Druker S, Schneider KL, et al. Weight gain prevention in the school worksite setting: results of a multi-level cluster randomized trial. Prev Med 2014;60:41-7.

29. Mansi S, Milosavljevic S, Tumilty S, Hendrick P, Higgs C, Baxter DG. Investigating the effect of a 3-month workplacebased pedometer-driven walking programme on health-related quality of life in meat processing workers: a feasibility study within a randomized controlled trial. BMC Public Health 2015; 15(1):410.

30. McEachan RR, Lawton RJ, Jackson C, Conner M, Meads DM, West RM. Testing a workplace physical activity intervention: a cluster randomized controlled trial. Int J Behav Nutr Phys Act 2011;8(1):29.

31. Morgan PJ, Collins CE, Plotnikoff RC, Cook AT, Berthon B, Mitchell S, et al. The impact of a workplace-based weight loss program on work-related outcomes in overweight male shift workers. J Occup Environ Med 2012;54(2):122-7.

32. Thøgersen-Ntoumani C, Loughren E, Duda J, Fox KR. Step by step: the feasibility of a 16-week workplace lunchtime walking intervention for physically inactive employees. J Phys Act Health 2014;11(7):1354-61.

33. Blake H, Zhou D, Batt ME. Five-year workplace wellness intervention in the NHS. Perspect Public Health 2013; 133(5):262-71.

34. Chae D, Kim S, Park Y, Hwang Y. The effects of an academic-workplace partnership intervention to promote physical activity in sedentary office workers. Workplace Health Saf 2015;63(6):259-66.

35. Edmunds S, Stephenson D, Clow A. The effects of a physical activity intervention on employees in small and medium enterprises: a mixed methods study. Work 2013;46(1):39-49.

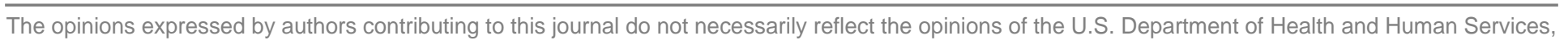
the Public Health Service, the Centers for Disease Control and Prevention, or the authors' affiliated institutions. 
36. Huang J-J, Lin H-S, Yen M, Kan W-M, Lee B-O, Chen C-H. Effects of a workplace multiple cardiovascular disease risks reduction program. Asian Nurs Res (Korean Soc Nurs Sci) 2013;7(2):74-82.

37. Taylor WC, Shegog R, Chen V, Rempel DM, Baun MP, Bush $\mathrm{CL}$, et al. The Booster Break program: description and feasibility test of a worksite physical activity daily practice. Work 2010;37(4):433-43.

38. Healy GN, Eakin EG, Lamontagne AD, Owen N, Winkler EA, Wiesner $G$, et al. Reducing sitting time in office workers: short-term efficacy of a multicomponent intervention. Prev Med 2013;57(1):43-8.

39. Pronk NP, Katz AS, Lowry M, Payfer JR. Reducing occupational sitting time and improving worker health: the Take-a-Stand Project, 2011. Prev Chronic Dis 2012;9:E154.

40. Flannery K, Resnick B, Galik E, Lipscomb J, McPhaul K, Shaughnessy M. The worksite heart health improvement project (WHHIP): feasibility and efficacy. Public Health Nurs 2012;29(5):455-66.

41. Hoert J, Herd AM, Hambrick M. The role of leadership support for health promotion in employee wellness program participation, perceived job stress, and health behaviors. Am J Health Promot 2016;0890117116677798.

42. Amaya M, Melnyk BM, Buffington B, Battista L. Workplace wellness champions: lessons learned and implications for future programming. Building Healthy Academic Communities Journal 2017;1(1):59-67.

43. Wolff MB, Gay JL, Wilson MG, DeJoy DM, Vandenberg RJ. Does organizational and coworker support moderate diabetes risk and job stress among employees? Am J Health Promot 2016.

44. Arena R, Guazzi M, Briggs PD, Cahalin LP, Myers J, Kaminsky LA, et al. Promoting health and wellness in the workplace: a unique opportunity to establish primary and extended secondary cardiovascular risk reduction programs. Mayo Clin Proc 2013;88(6):605-17.

45. Dickson-Swift V, Fox C, Marshall K, Welch N, Willis J. What really improves employee health and wellbeing: findings from regional Australian workplaces. Int J Workplace Health Manag 2014;7(3):138-55.

46. Kaspin LC, Gorman KM, Miller RM. Systematic review of employer-sponsored wellness strategies and their economic and health-related outcomes. Popul Health Manag 2013; 16(1):14-21.

47. Caesens G, Stinglhamber F, Ohana M. Perceived organizational support and well-being: a weekly study. J Manag Psychol 2016;31:1214-30.
48. Grawitch M, Gottschalk M, Munz D. The path to a healthy workplace: a critical review linking healthy workplace practices, employee well-being, and organizational improvements. Consulting Psychology Journal: Practice and Research 2006;58:129-47.

49. Rongen A, Robroek SJ, van Ginkel W, Lindeboom D, Pet M, Burdorf A. How needs and preferences of employees influence participation in health promotion programs: a six-month follow-up study. BMC Public Health 2014;14(1):1277.

50. Escoto KH, Laska MN, Larson N, Neumark-Sztainer D, Hannan PJ. Work hours and perceived time barriers to healthful eating among young adults. Am J Health Behav 2012;36(6):786-96.

\footnotetext{
The opinions expressed by authors contributing to this journal do not necessarily reflect the opinions of the U.S. Department of Health and Human Services, the Public Health Service, the Centers for Disease Control and Prevention, or the authors' affiliated institutions.
} 


\section{Tables}

Table 1. Organizational Supports Components and Physical Activity Components of CDC's Health ScoreCard ${ }^{\text {a }}$

\begin{tabular}{|c|c|c|}
\hline Component & $\begin{array}{l}\text { Yes, No. of } \\
\text { Points }\end{array}$ & $\begin{array}{l}\text { No, No. of } \\
\text { Points }\end{array}$ \\
\hline \multicolumn{3}{|l|}{ Organizational supports: During the past 12 months, did your worksite ... } \\
\hline Conduct an employee needs and interests assessment for planning health promotion activities? & 1 & 0 \\
\hline $\begin{array}{l}\text { Conduct employee health risk appraisals/assessments through vendors, on-site staff, or health plans and provide individual } \\
\text { feedback plus health education? }\end{array}$ & 3 & 0 \\
\hline Demonstrate organizational commitment and support of worksite health promotion at all levels of management? & 2 & 0 \\
\hline Use and combine incentives with other strategies to increase participation in health promotion programs? & 2 & 0 \\
\hline Use competitions when combined with additional interventions to support employees making behavior changes? & 2 & 0 \\
\hline Promote and market health promotion programs to employees? & 1 & 0 \\
\hline $\begin{array}{l}\text { Use examples of employees role modeling appropriate health behaviors or employee health-related "success stories" in the } \\
\text { marketing materials? }\end{array}$ & 1 & 0 \\
\hline $\begin{array}{l}\text { Tailor some health promotion programs and education materials to the language, literacy levels, culture, or readiness to } \\
\text { change of various segments of the workforce? }\end{array}$ & 3 & 0 \\
\hline Have an active health promotion committee? & 2 & 0 \\
\hline $\begin{array}{l}\text { Have a paid health promotion coordinator whose job (either part-time or full-time) is to implement a worksite health } \\
\text { promotion program? }\end{array}$ & 2 & 0 \\
\hline Have a champion(s) who is a strong advocate for the health promotion program? & 2 & 0 \\
\hline Have an annual budget or receive dedicated funding for health promotion programs? & 2 & 0 \\
\hline Set annual organizational objectives for health promotion? & 2 & 0 \\
\hline $\begin{array}{l}\text { Include references to improving or maintaining employee health in the business objectives or organizational mission } \\
\text { statement? }\end{array}$ & 1 & 0 \\
\hline Conduct ongoing evaluations of health promotion programming that use multiple data sources? & 2 & 0 \\
\hline Make any health promotion programs available to family members? & 1 & 0 \\
\hline Provide flexible work scheduling policies? & 2 & 0 \\
\hline Engage in other health initiatives throughout the community and support employee participation and volunteer efforts? & 2 & 0 \\
\hline \multicolumn{3}{|l|}{ Your worksite's organizational supports section score (total points possible: 33 ) } \\
\hline \multicolumn{3}{|l|}{ Physical activity: During the past 12 months, did your worksite... } \\
\hline Provide an exercise facility on-site? & 3 & 0 \\
\hline Subsidize or discount the cost of on-site or off-site exercise facilities? & 3 & 0 \\
\hline Provide environmental supports for recreation or physical activity? & 3 & 0 \\
\hline Post signs at elevators, stairwell entrances or exits and other key locations that encourage employees to use the stairs? & 3 & 0 \\
\hline Provide organized individual or group physical activity programs for employees (other than the use of an exercise facility)? & 3 & 0 \\
\hline $\begin{array}{l}\begin{array}{l}\text { Provide brochures, videos, posters, pamphlets, newsletters, or other written or online information that address the benefits of } \\
\text { physical activity? }\end{array} \\
\end{array}$ & 1 & 0 \\
\hline Provide a series of educational seminars, workshops, or classes on physical activity? & 2 & 0 \\
\hline $\begin{array}{l}\text { Provide or subsidize physical fitness assessments, follow-up counseling, and physical activity recommendations either on-site } \\
\text { or through a community exercise facility? }\end{array}$ & 3 & 0 \\
\hline Provide free or subsidized self-management programs for physical activity? & 3 & 0 \\
\hline Your worksite's physical activity section score (total points possible: 24 ) & & \\
\hline
\end{tabular}

${ }^{a}$ Adapted from the Centers for Disease Control and Prevention's Worksite Health ScoreCard (11). 
Table 2. Summary of Worksite Health Promotion Programs Identified in a Scoping Review That Used the CDC's Worksite Health ScoreCard ${ }^{a}$ as a Framework to Examine Worksite Health Promotion and Physical Activity

\begin{tabular}{|c|c|c|c|c|c|c|}
\hline Author, Year & Study Design & $\begin{array}{l}\text { Single or } \\
\text { Multiple } \\
\text { Worksites }\end{array}$ & $\begin{array}{c}\text { Target Behavior or } \\
\text { Disease }\end{array}$ & Sample Population & $\begin{array}{c}\text { Significantly } \\
\text { Improved } \\
\text { Physical Activity }\end{array}$ & $\begin{array}{l}\text { Type of Physical Activity } \\
\text { Improvement }\end{array}$ \\
\hline $\begin{array}{l}\text { Aldana et al (23), } \\
2005\end{array}$ & $\begin{array}{l}\text { 4-week RCT with } \\
\text { untreated control } \\
\text { group }\end{array}$ & Single & $\begin{array}{l}\text { Physical activity } \\
\text { and diet }\end{array}$ & Rockford, Illinois ( $n=145$ ) & Yes & Total steps per week \\
\hline $\begin{array}{l}\text { Blake et al (33) } \\
(2013)\end{array}$ & $\begin{array}{l}\text { 5-year ecological } \\
\text { study }\end{array}$ & Single & $\begin{array}{l}\text { Physical activity, } \\
\text { well-being (general } \\
\text { health and mood), } \\
\text { stress and diet }\end{array}$ & $\begin{array}{l}\text { National Health Services } \\
\text { employees in the United } \\
\text { Kingdom }(n=1,134)\end{array}$ & Yes & $\begin{array}{l}\text { Activity at work, active travel to } \\
\text { work, walking or cycling for at least } \\
10 \text { min, meeting physical activity } \\
\text { guidelines }\end{array}$ \\
\hline $\begin{array}{l}\text { Jules Pretty et al } \\
\text { (24) (2014) }\end{array}$ & $\begin{array}{l}\text { 8-week parallel- } \\
\text { group randomized } \\
\text { controlled trial }\end{array}$ & Multiple & Physical activity & $\begin{array}{l}\text { Desk-based employees of } \\
\text { the Financial Times and } \\
\text { London Stock Exchange in } \\
\text { the United Kingdom ( } \mathrm{n}= \\
\text { 73) }\end{array}$ & No & None \\
\hline $\begin{array}{l}\text { Campbell et al } \\
(25)(2002)\end{array}$ & $\begin{array}{l}\text { 18-month } \\
\text { randomized } \\
\text { experimental } \\
\text { design }\end{array}$ & Multiple & $\begin{array}{l}\text { Physical activity, } \\
\text { diet, smoking, and } \\
\text { cancer screening }\end{array}$ & $\begin{array}{l}\text { Rural, blue-collar women } \\
\text { working in eastern North } \\
\text { Carolina }(n=538)\end{array}$ & Yes & Stretching and flexibility exercises \\
\hline $\begin{array}{l}\text { Chae et al (34) } \\
\text { (2015) }\end{array}$ & $\begin{array}{l}\text { 8-week single- } \\
\text { group } \\
\text { pretest-posttest } \\
\text { pilot study }\end{array}$ & Single & Physical activity & $\begin{array}{l}\text { Sedentary office workers } \\
\text { from an airline company in } \\
\text { Seoul, South Korea }(n= \\
70)\end{array}$ & Yes & Daily steps \\
\hline $\begin{array}{l}\text { Chau et al (26) } \\
(2014)\end{array}$ & $\begin{array}{l}\text { 4-week } \\
\text { randomized } \\
\text { controlled trial } \\
\text { pilot design }\end{array}$ & Single & $\begin{array}{l}\text { Physical activity } \\
\text { and sitting time }\end{array}$ & $\begin{array}{l}\text { Non-government health } \\
\text { agency in New South } \\
\text { Wales, Australia }(n=42)\end{array}$ & Yes & $\begin{array}{l}\text { Decreased sitting time and } \\
\text { increased standing at work }\end{array}$ \\
\hline $\begin{array}{l}\text { Edmunds et al } \\
\text { (35) (2013) }\end{array}$ & $\begin{array}{l}\text { 6-month single- } \\
\text { arm repeated } \\
\text { measures design }\end{array}$ & Multiple & $\begin{array}{l}\text { Physical activity } \\
\text { and well-being }\end{array}$ & $\begin{array}{l}\text { Low-active employees from } \\
17 \text { small and medium- } \\
\text { sized organizations in the } \\
\text { United Kingdom }(n=89)\end{array}$ & Yes & Days per week of physical activity \\
\hline $\begin{array}{l}\text { Flannery et al } \\
\text { (40) (2012) }\end{array}$ & $\begin{array}{l}\text { 3-month quasi- } \\
\text { experimental pilot }\end{array}$ & Multiple & $\begin{array}{l}\text { Physical activity } \\
\text { and diet }\end{array}$ & $\begin{array}{l}\text { Nursing assistants in a } \\
\text { long-term care facility in } \\
\text { Baltimore, Maryland }(n= \\
\text { 39) }\end{array}$ & No & None \\
\hline $\begin{array}{l}\text { Healy et al (38) } \\
(2013)\end{array}$ & $\begin{array}{l}\text { 4-week non- } \\
\text { randomized } \\
\text { controlled trial }\end{array}$ & Single & $\begin{array}{l}\text { Physical activity } \\
\text { and sitting time }\end{array}$ & $\begin{array}{l}\text { Government office workers } \\
\text { in Melbourne, Australia ( } \mathrm{n} \\
=43 \text { ) }\end{array}$ & Yes & $\begin{array}{l}\text { Decreased sitting time and } \\
\text { increased standing at work }\end{array}$ \\
\hline $\begin{array}{l}\text { Huang et al (36) } \\
(2013)\end{array}$ & $\begin{array}{l}\text { 6-month pilot } \\
\text { pretest-posttest }\end{array}$ & Single & $\begin{array}{l}\text { Physical activity, } \\
\text { diet, stress } \\
\text { management, } \\
\text { medication } \\
\text { adherence, and } \\
\text { alcohol } \\
\text { consumption }\end{array}$ & $\begin{array}{l}\text { Manufacturing employees } \\
\text { in Taiwan, China, with high } \\
\text { blood pressure, } \\
\text { cholesterol, or triglycerides } \\
(n=283)\end{array}$ & Yes & $\begin{array}{l}\text { Increased physical activity } \\
\text { readiness-to-change stage }\end{array}$ \\
\hline $\begin{array}{l}\text { Irvine et al (27) } \\
\text { (2011) }\end{array}$ & $\begin{array}{l}\text { 1-month } \\
\text { randomized } \\
\text { controlled trial }\end{array}$ & Single & Physical activity & $\begin{array}{l}\text { Sedentary employees } \\
\text { working at a large } \\
\text { manufacturing plant in } \\
\text { Oregon }(n=228)\end{array}$ & Yes & $\begin{array}{l}\text { Minutes per day of physical activity } \\
\text { and current exercise status }\end{array}$ \\
\hline $\begin{array}{l}\text { Lemon et al (28) } \\
(2014)\end{array}$ & $\begin{array}{l}\text { 24-month cluster } \\
\text { randomized trial }\end{array}$ & Multiple & $\begin{array}{l}\text { Physical activity } \\
\text { and diet }\end{array}$ & $\begin{array}{l}12 \text { public high schools in } \\
\text { Worcester, Massachusetts } \\
(n=782)\end{array}$ & No & $\begin{array}{l}\text { Not applicable: intervention } \\
\text { assessed body mass index, } \\
\text { participation in physical activity } \\
\text { events, and implementation of } \\
\text { physical activity policies at the } \\
\text { organization level but not } \\
\text { individuals' physical activity } \\
\text { behavior }\end{array}$ \\
\hline
\end{tabular}

\footnotetext{
${ }^{a}$ Adapted from the Centers for Disease Control and Prevention's Worksite Health ScoreCard (11).
}

${ }^{\mathrm{b}}$ Physical activity improvements were reported to be significant $(P<.05)$. 
(continued)

Table 2. Summary of Worksite Health Promotion Programs Identified in a Scoping Review That Used the CDC's Worksite Health ScoreCard ${ }^{a}$ as a Framework to Examine Worksite Health Promotion and Physical Activity

\begin{tabular}{|c|c|c|c|c|c|c|}
\hline Author, Year & Study Design & $\begin{array}{l}\text { Single or } \\
\text { Multiple } \\
\text { Worksites }\end{array}$ & $\begin{array}{l}\text { Target Behavior or } \\
\text { Disease }\end{array}$ & Sample Population & $\begin{array}{c}\text { Significantly } \\
\text { Improved } \\
\text { Physical Activity }\end{array}$ & $\begin{array}{l}\text { Type of Physical Activity } \\
\text { Improvement }\end{array}$ \\
\hline $\begin{array}{l}\text { Mansi et al (29) } \\
(2015)\end{array}$ & $\begin{array}{l}\text { 3-month } \\
\text { randomized } \\
\text { controlled trial }\end{array}$ & Single & Physical activity & $\begin{array}{l}\text { Meat-processing workers } \\
\text { in New Zealand }(n=58)\end{array}$ & No & None \\
\hline $\begin{array}{l}\text { McEachan et al } \\
\text { (30) (2011) }\end{array}$ & $\begin{array}{l}\text { 3-month matched- } \\
\text { pairs cluster } \\
\text { randomized } \\
\text { controlled trial }\end{array}$ & Multiple & Physical activity & $\begin{array}{l}44 \text { worksites in United } \\
\text { Kingdom }(n=1,260)\end{array}$ & No & None \\
\hline $\begin{array}{l}\text { Morgan et al (31) } \\
(2012)\end{array}$ & $\begin{array}{l}\text { 3-month } \\
\text { randomized } \\
\text { controlled trial with } \\
\text { wait-list controls }\end{array}$ & Single & $\begin{array}{l}\text { Physical activity } \\
\text { and diet }\end{array}$ & $\begin{array}{l}\text { Male shift workers in New } \\
\text { Castle, New South Wales } \\
(n=110)\end{array}$ & No & None \\
\hline $\begin{array}{l}\text { Pronk et al (39) } \\
\text { (2012) }\end{array}$ & $\begin{array}{l}\text { 4-week non- } \\
\text { randomized time } \\
\text { series }\end{array}$ & Single & Sitting time & $\begin{array}{l}\text { Sedentary workers in } \\
\text { Minneapolis, Minnesota ( } \mathrm{n} \\
=34 \text { ) }\end{array}$ & Yes & Decreased sitting time at work \\
\hline $\begin{array}{l}\text { Taylor et al (37) } \\
(2010)\end{array}$ & $\begin{array}{l}\text { 6-month pre-post } \\
\text { pilot study }\end{array}$ & Single & Physical activity & $\begin{array}{l}\text { Small legal business } \\
\text { employees in the United } \\
\text { States }(n=14)\end{array}$ & No & None \\
\hline $\begin{array}{l}\text { Thøgersen- } \\
\text { Ntoumani et al } \\
\text { (32) (2014) }\end{array}$ & $\begin{array}{l}\text { 16-week feasibility } \\
\text { trial }\end{array}$ & Single & Physical activity & $\begin{array}{l}\text { Non-academic university } \\
\text { employees in the United } \\
\text { Kingdom who did not meet } \\
\text { current physical activity } \\
\text { recommendations }(n=75 \text { ) }\end{array}$ & Yes & $\begin{array}{l}\text { Time spent active during the week if } \\
\text { group-led walk }\end{array}$ \\
\hline
\end{tabular}

\footnotetext{
${ }^{\text {a }}$ Adapted from the Centers for Disease Control and Prevention's Worksite Health ScoreCard (11).
}

${ }^{\mathrm{b}}$ Physical activity improvements were reported to be significant $(P<.05)$. 
Table 3. Frequency of Use of CDC's Health ScoreCard ${ }^{a}$ Strategies by Physical Activity Worksite Health Promotion Programs That Improved Physical Activity and Programs That Did Not

\begin{tabular}{|c|c|c|c|}
\hline Health ScoreCard Strategy, by Point Value ${ }^{b}$ & $\begin{array}{l}\text { Overall Use of Strategy, } \\
\text { No. of Studies }(n=18)\end{array}$ & $\begin{array}{l}\text { Use of Strategy Improved } \\
\text { Physical Activity, No. of Studies } \\
(n=11)\end{array}$ & $\begin{array}{l}\text { Use of Strategy Did Not Improve } \\
\text { Physical Activity, No. of Studies } \\
\qquad(n=7)\end{array}$ \\
\hline \multicolumn{4}{|c|}{ Organizational Supports } \\
\hline \multicolumn{4}{|l|}{ Best } \\
\hline Conduct employee health risk appraisal/assessment & 3 & 3 & 0 \\
\hline Tailor program/materials to segments of workforce & 5 & 3 & 2 \\
\hline \multicolumn{4}{|l|}{ Better } \\
\hline $\begin{array}{l}\text { Demonstrate organizational commitment of worksite health } \\
\text { promotion at all levels of management }\end{array}$ & 8 & 6 & 2 \\
\hline Use/combine incentives with other strategies & 10 & 7 & 3 \\
\hline Use competitions to support behavior changes & 5 & 2 & 3 \\
\hline Have an active health promotion committee & 3 & 3 & 0 \\
\hline Have paid health promotion coordinator & 4 & 2 & 2 \\
\hline Have champion(s) who advocates for program & 7 & 3 & 4 \\
\hline Set annual health promotion organizational objectives & 1 & 1 & 0 \\
\hline $\begin{array}{l}\text { Conduct ongoing evaluation of program using multiple } \\
\text { sources }\end{array}$ & 18 & 11 & 7 \\
\hline Provide flexible work scheduling policies & 5 & 3 & 2 \\
\hline Engage in other community health initiatives & 1 & 1 & 0 \\
\hline \multicolumn{4}{|l|}{ Good } \\
\hline Conduct employee needs /interest assessments & 1 & 1 & 0 \\
\hline $\begin{array}{l}\text { Promote /market worksite health promotion programs to } \\
\text { employees }\end{array}$ & 9 & 6 & 3 \\
\hline Use role modeling/success stories in marketing materials & 1 & 0 & 1 \\
\hline $\begin{array}{l}\text { Include employee health in business objectives/mission } \\
\text { statement }\end{array}$ & 1 & 0 & 1 \\
\hline Make programs available to family members & 1 & 1 & 0 \\
\hline \multicolumn{4}{|c|}{ Physical activity } \\
\hline \multicolumn{4}{|l|}{ Best } \\
\hline Provided exercise facility on-site & 4 & 2 & 2 \\
\hline Subsidize/discount cost of exercise facilities & 2 & 2 & 0 \\
\hline Provide other environmental supports & 5 & 2 & 3 \\
\hline Post signs that encourage stair use & 1 & 1 & 0 \\
\hline Provide organized physical activity programs to employees & 9 & 5 & 4 \\
\hline $\begin{array}{l}\text { Provide/subsidize fitness assessments, follow-up counseling, } \\
\text { and PA recommendations }\end{array}$ & 5 & 3 & 2 \\
\hline \multicolumn{4}{|l|}{ Better } \\
\hline Provide PA seminars/classes/workshops & 9 & 7 & 2 \\
\hline \multicolumn{4}{|l|}{ Good } \\
\hline Provide information on the benefits of PA & 11 & 7 & 4 \\
\hline
\end{tabular}

${ }^{a}$ Adapted from the Centers for Disease Control and Prevention's Worksite Health ScoreCard (11).

${ }^{\mathrm{b}}$ The HSC assigns point values of 1,2 , or $3(1=$ good, $2=$ better, and $3=$ best) to indicate the level of effect each strategy has on the associated health topic or outcome and the strength of evidence for this effect.

The opinions expressed by authors contributing to this journal do not necessarily reflect the opinions of the U.S. Department of Health and Human Services, the Public Health Service, the Centers for Disease Control and Prevention, or the authors' affiliated institutions. 